\section{IMPLEMENTING THE FLIPPED COMPUTER SCIENCE LEARNING APPROACH TO FOSTER LEARNING AUTONOMY SKILLS: A QUALITATIVE STUDY WITHIN COMPULSORY EDUCATION}

\author{
M. Alwaqdani ${ }^{1}$, C. Walker-Gleaves ${ }^{2}$ \\ ${ }^{1}$ Mohammed S Alwaqdani, Doctoral Candidate, \\ Newcastle University \\ ${ }^{2}$ Caroline Walker-Gleaves, Professor of Education, \\ Newcastle University
}

\begin{abstract}
Over the last decade, a major innovation within technology use in order to transform students' learning has developed in higher education worldwide. One key technology adaptation that has attracted much attention, because of its facilitation of the practice of the active learning, is 'flipped learning' which aims to enhance students' engagement and promote self-directed learning. Flipped learning has been introduced into various disciplines and at educational levels, with a number of promising educational gains in terms of improved student learning experiences. However, despite an encouraging body of research, the high school level has not yet been explicitly researched in terms of how flipped learning may enhance learning autonomy skills. In parallel, there is a pressing need in education to cultivate students' autonomous learning in and out of school, a need that has become all too apparent during the Covid19 pandemic. This paper aimed to investigate how a flipped learning environment could enhance Computer Science students' learning autonomy in a high school. It discusses findings from a qualitative study investigating the learning autonomy of students in flipped and non-flipped learning contexts, to understand differences between students' autonomous learning in these two learning environments. Data were gathered via 18 semi-structured interviewers and two focus groups that were then analysed using a thematic analysis approach. The findings from flipped learning participants and non-flipped learning participants showed that the students in the flipped learning conditions hold a more positive attitude toward their learning autonomy compared to students in the non-flipped learning context. Furthermore, the students in the flipped learning environment showed an awareness of being autonomous learners compared with non-flipped learning students who depended heavily upon the teacher for their learning and motivation. The study showed how flipped learning can promote student motivation to learn independently by providing learning practices that allow the students to
\end{abstract}

practice their autonomy learning skill over time, which then develop into habits of mind. The study suggested that the computer teacher could implement the flipped learning approach with the aim of enhancing the students' learning autonomy skills through the learning processes, including preclassroom activities and in-classroom activities.

Keywords: Flipped Learning, Learning Autonomy, Computer Science, High School.

\section{INTRODUCTION}

Nurturing students' autonomous learning in and out of school is one of the aims of education across the world in general and in Saudi Arabia in particular. School learning outcomes should encompass being equipped with autonomous learning skills given their significance for the workplace [1]. Moreover, success at the university level can be considered as an another factor for the importance of independent learning [2]. Further, it is clearly the case that conventional modes of learning and teaching, including lectures, do not appear to be in keeping with the autonomous learning framework given that teachers frequently shoulder most of the responsibility, leaving their students on the fringe of the learning process. In contrast, autonomous learning allows for reversal of roles and responsibilities between the teacher and the learners throughout the learning experience. As such, it can be said that the suitable options for autonomous learning include those teaching methods that employ the concept of active learning and student-centred learning [3]. Indeed, the importance of autonomous learning skills has been evidently shown in the Covid-19 crisis where many schools world-wide had to close and shift the learning process away from educational institutions and have it undertaken as home or remote education. There is no doubt that the education sector has suddenly found itself a hostage of the middle of the Covid-19 virus, changing much of people's views on instruction and how it should be delivered. As opposed to experiences that are pre-planned and intended for online instruction, and in response to these exceptional circumstances, a provisional change of teaching delivery to an alternative delivery method, which is emergency remote teaching (ERT), has been undertaken in many education settings [4]. The issue with this is that students have not been used to taking charge of their learning because past learning experiences did not provide the opportunity for them to practise autonomous learning skills. An interesting find of such emergency remote learning in the time of Covid-19 is that the teachers and policymakers have been 
able to use such challenging circumstances to their advantage and encourage their students to embrace learning autonomy. It is therefore curial that the teachers consider this issue seriously and attempt to provide the students with a vital learning experience and the opportunity to practise skills, such as autonomous learning in order to overcome crises such as that of Covid-19. Also arising from this new normal is that teaching methods could be subject to modification, thus giving the students more of a key role in the learning process and shifting the focus to a more student-centred approach.

In parallel with these changes, a great deal of attention in the literature has been given to the importance of ICT and Learning Technology for autonomous learning [3]. It is possible to provide independent or autonomous learning skills as part of educational practice, including the flipped learning approach (FL). The students will then be able to utilise their experience to gain access to this online platform as a pre-classroom activity, which in turn allows them to play a key role in collaborative learning activities when in a classroom situation. Flipped learning offers selflearning methods that are pre-class based, such as watching videos, listening to podcasts and reading materials. This method has recently been exposed as one of the most creative learning approaches that have been introduced into educational settings. Effective implementation of a flipped learning approach will avail teachers with a practical tool through which they can dedicate more time to their students in terms of providing assistance and guidance with difficult activities, lab work, research materials and resources, which will eventually enable students to be more autonomous and in charge of their own learning $[5,6]$. The aim of this paper is to examine how the flipped learning approach can improve Computer Science students' learning autonomy within a high school learning context. Findings from a qualitative study exploring the learning autonomy of students in flipped and non-flipped learning contexts will be discussed in order to understand differences between students' autonomous learning in these two learning settings. A total of 18 semi-structured interviewers and two focus groups were used to gather data, which was then analysed using a thematic analysis approach.

\section{METHODOLOGY}

To gain an in-depth understanding on how a flipped learning environment could develop Computer Science students' learning autonomy, the qualitative methods were utilised. According to
Giannakos, Krogstie [7], it seems that there has not been much focus was directed to qualitativeoriented studies in terms of studies carried out on the flipped learning approach. In this paper, the methodology employed was one based around interpretive qualitative methods, more specifically the interview and focus group tools. Through faceto-face interviews, the researcher was able to give students more freedom to express themselves, while the participants were allowed to probe their views in the focus group. In fact, use of these two research instruments not only enabled the researcher to yield very rich data about learners' views and experiences [8], but to ensure findings could be validated through the process of triangulation. The first qualitative method used was a semi-structured interview with 18 students ( 9 for each group), which allows views and thoughts to be expanded upon during the interview process [9]. The focus groups was the other type of strategy used in the current qualitative research, through which it was possible for the researcher to gain an insight into the students' viewpoints towards how their learning preferences [10]. After collecting data using 18 semi-structured interviewers and two focus groups, a thematic analysis approach was employed in the data analysis process. As suggested by Nowell et al. [11], thematic analysis may prove key when it comes to examining the opinions of different research participants, highlighting similarities and differences, and generating unanticipated results.

\subsection{Sample and Procedure}

The target population for this research study included Saudi high school 1st-grade students from two Computer Science classrooms, with one class taught using the flipped learning approach and the second using the non-flipped learning approach. The students in flipped learning were exposed to learning over two phases; a pre-classroom phase where they were expected to prepare for the classroom at home using online materials, such as instructional videos, and online quizzes. In the second phase, the teacher had to engage the students in problem-solving and collaboration activities to apply what they had learnt in preclassroom phase. After Week 12 in the first term, the students were offered the chance to participate in the interview and focus group.

\section{RESULTS}

Analysis of illustrative and selected data extracted from the interviews and focus group identified three themes pinpointing how the flipped learning approach could foster the students learning autonomy and how the difference between the 
flipped learning environment and non-flipped learning environment can play a role in nurturing students' learning skills.

\subsection{General attitudes of students towards their learning autonomy}

The respondents provided their accounts in relation to learning autonomy. According to the findings, the students in flipped learning felt somewhat autonomous when learning. For instance, student in the flipped learning group (FLG) reported that the learning process was useful in terms of motivating them to be self-dependent learning about Computer subjects, as well as fostering their keenness on learning Computer Sciences using a computer. In contrast, non-flipped learning (NFLG) students reported their reliance on the teacher in the lesson explanation, which was followed by the usual home revision. When confronted with difficult concepts, they had to depend on the Internet not the textbook, which was not helpful. Significantly, it appears that the students in FLG showed far more confidence and thus selfautonomy by investing in external opportunities, including online materials, than the students in NFLG who seemed to be powerlessly dependent on the teacher for their learning. Interestingly, during the discussion, the students in FLG exemplified their ability to learn by themselves. For example, it was possible for one student to write a note during the video and review it before the quiz. If mistakes occurred, he would re-watch the video to correct himself before the actual lesson. It can be safely suggested that based on the flipped learning approach, the processes of studying online materials and being engaged in detailed classroom activities are very much central, which, provided that student are motivated to learn, can enhance students' learning autonomy.

"The learning process helped me to depend on myself and learn via video and online materials ... I think the reason was that the learning method was interesting for me like watching videos and answering quizzes. Also, because we are learning about computers by using computers" FLG1

\subsection{Awareness of learning autonomy}

According to the data obtained from the discussion with the focus groups concerning their learning autonomy, all participants reported that flipped learning has somehow enhanced their independence when learning Computer Science. Students in the focus group have all felt the same, stating that "my learning depends on me"; "we can manage our learning and learn by ourselves"; "we were responsible for accessing online and preparing for the lesson before coming to class"; and "you can see all steps of learning depend on us", respectively. It goes to show that not only has the flipped learning process had an effect on their learning autonomy, but it also reflects on their understanding of being self-dependent learners. As for NFLG, and as clearly indicated in the students' responses, it can be easily inferred that the teacher has a strong presence in the process, which has had an adverse effect on their autonomous learning skills. In terms of the findings of the interviews, students reported that the learning process was not empowering, and they did not take charge of their learning. For example, NFLG 9 stated that "I did not do much self-learning because the role of teacher is to deliver the lesson and my role is to revise I tat home." In addition, the students pointed out that they had to rely on what the teacher had to give them, to which they were grateful and reverent as they deemed his role important because he knew what was right and was in charge of the exam. This shows that the students in the NFLG do not seem to be aware of learning autonomy as much as they recognise the importance of the teacher as the only source of knowledge.

\subsection{Useful affordances of flipped learning in students' autonomous learning}

In this theme, the useful affordances of flipped learning in terms of improving students' learning autonomy are highlighted. Students in the interview showed great enthusiasm in their justification of how flipped learning had been useful changing their learning approach. FL was also helpful in terms of not only making students autonomous learners and appealing to their learning style, but it also provided them with some background idea about the lesson expectations and outcomes, such as the learning objectives and lesson plans in order to be more organised and better prepared.

\footnotetext{
"... I did not like reading textbooks... I am a person who likes to listen and watch when learning something ... So, videos and online discussions facilitated my own learning. Also, flipped learning has given me a sense of responsibility and confidence to learn by myself in my own style." FLG2
}

"I like that the teacher writes the headline and leaning objectives 
every week on the front page of the learning system, and this helps me to see what I will learn. Then I can manage my time to study every day for one hour based on the learning objectives, and I also know what I will have in the classroom. It is similar to an online course. " FLG4

By offering the students in FLG a learning plan, they were able to manage their learning at their leisure. In addition, FL enabled the students to claim full ownership of their learning and to study at their own pace. For example, Student FLG5 and Student FLG6 clearly demonstrated how learning beyond school in the flipped learning approach was beneficial for them to study and work independently. Similarly, the students mentioned supplementary elements, including the quiz, in that they were useful in terms of gauging their understanding as part of a novel self-learning process. As such, offering an evaluation mechanism in the flipped learning design could contribute to the students' autonomous learning.

"My self-learning was good because I study at home and not just in the school. Also, I studied without any pressure and distraction, which helped me to achieve the learning objectives that the teacher set for us. I studied and wrote all the information to be ready for the classroom activities ... I do not want to come to class as a nondiligent student. The learning practice shows how I can learn by myself." FLG5

"In the past, the learning was dependent on the teacher and the learning was just in the school ... Now, I do put more effort at home ... I can study in my own time and re-watch the lesson many times until I fully understand, and if I need help, I can let the teacher know in the classroom. This new method of learning gave me more confidence and will help me at university in the future ... My brother told me it would be helpful for me at the university level." FLG6

\section{CONCLUSIONS AND DISCUSSION}

According to the findings, it can be clearly shown that based on their learning experiences in the flipped learning environment, the Computer Science students had a positive attitude towards their self-learning. Compared to their counterparts in NFLG, the students felt more autonomous and in charge of their learning. In addition, an interesting finding was that flipped learning enhanced the students' awareness about gaining learning autonomy skills, in comparison to non-flipped learning. This paper is congruent with the previous studies in stating that implementation of flipped learning could have a positive impact in terms of gaining higher learner autonomy (e.g. [5, 12]). From the findings, it is evident that the flipped learning approach is useful for the students' learning practices, such as preparation for the classroom, using online quizzes to evaluate their understanding and engagement in classroom activities. The use of such learning practices can help the students to with their learning autonomy skills. As stated by Gandhimathi [13], autonomy has a direct link with metacognitive approaches which involve considering the learning process, preparing for learning, supervising the learning task, and selfassessment.

In addition, the findings illustrated that flipped learning can meet the students' learning style which might enhance their learning autonomy. Furthermore, the flipped learning approach allowed the students to manage their out-ofclassroom learning, which seems to provide the opportunity for students to acquire the skills to be autonomous learners. Furthermore, providing the students with background ideas about the lesson and the learning objects was one of the learning practices that seemed to help students to learn independently where the students could set a plan for pre-classroom learning and know what the teacher expected from them in the classroom. Finally, it was clear that the students in flipped learning were active learners in the learning environment be it pre-classroom and in-classroom, which as a result seemed to foster their learning autonomy skills compared to non-flipped learning environment where the students appeared to be inactive. Hutapea [14] stated that learning autonomy cannot be attained if learners are not actively engaged. Being inactive, Computer Science students tended to copy the tasks and follow the procedure explained by their teacher [14].

In conclusion, Computer Science teachers might implement flipped learning in order to provide their students with the opportunity to practise 
autonomy skills in such a vital learning environment. Fostering the students' learning autonomy can therefore arguably help in the future in terms of preparing the students to face and overcome difficulties facing their education progress in such a crisis like Covid-19 and to be ready for the shift in learning from on-campus to emergency remote education. The students in the Covid-19 new normal have had to face insurmountable difficulties with school closures and moving on to distance learning, which needs higher motivation and sophisticated skills to learn independently. This paper has showed how flipped learning enables the students to manage their learning and take ownership of it through preclassroom and in-classroom activities, in addition to developing awareness about their autonomous learning skills, which could help them in case a future emergency educational event is called upon. In addition, the students may also find these skills useful in their future career given the demand for such skills in the modern-day workplace.

\section{ACKNOWLEDGEMENTS}

The author would like to thank the government of Saudi Arabia for providing him with a study scholarship and for the support he has received to complete his higher education in the UK.

\section{REFERENCES}

1. Luna Scott, C., The Futures of Learning 3: what kind of pedagogies for the 21st century? 2015.

2. Field, R.M., J. Duffy, and A. Huggins, Independent learning skills, Selfdetermination theory and psychological well-being: Strategies for supporting the first year university experience. 2014.

3. Meyer, W. Independent learning: a literature review and a new project. in British Educational Research Association Annual Conference, University of Warwick. 2010.

4. Hodges, C., et al., The difference between emergency remote teaching and online learning. Educause Review, 2020. 27.

5. Bergmann, J. and A. Sams, Flip your classroom: Reach every student in every class every day. 2012: International Society for Technology in Education.

6. Hamdan, N., et al., The flipped learning model: A white paper based on the literature review titled a review of flipped learning. 2013: Flipped Learning Network/Pearson/George Mason University.
7. Giannakos, M.N., J. Krogstie, and D. Sampson, Putting flipped classroom into practice: A comprehensive review of empirical research, in Digital technologies: Sustainable innovations for improving teaching and learning. 2018, Springer. p. 27-44.

8. Xerri, D., The Use of Interviews and Focus Groups in Teacher Research. The Clearing House: A Journal of Educational Strategies, Issues and Ideas, 2018. 91(3): p. 140-146.

9. Denscombe, M., The good research guide : for small-scale social research projects. Fifth edition.. ed, ed. d. Ebooks Corporation Limited. 2014: Maidenhead, Berkshire : Open University Press.

10. Bryman, A., Social research methods. Fifth edition.. ed. 2016: Oxford, United Kingdom : Oxford University Press.

11. Nowell, L.S., et al., Thematic Analysis:Striving to Meet the Trustworthiness Criteria. International Journal of Qualitative Methods, 2017. 16(1): p. 1609406917733847.

12. Wulandari, M., Fostering learning autonomy through the implementation of flipped learning in language teaching media course. International Journal of Indonesian Education and Teaching (IJIET), 2017. 1(2): p. 194-205.

13. Gandhimathi, S. and A. Devi, Learner autonomy and motivation-a literature review. Research on Humanities and Social Sciences, 2016. 6(3): p. 80-83.

14. Hutapea, N.M., Improving Senior High School Students Learning Autonomy through Generative Learning. Journal of Educational Sciences, 2019. 3(1): p. 84-95. 